\title{
コンクリート充填角形鋼管柱・鉄骨梁接合部局部の弾塑性性状に関する研究
} 一内ダイアフラム形式及び通しダイアフラム形式の簡易荷重 - 変形関係モデルー

\section{LOCAL ELASTO-PLASTIC BEHAVIOR OF STEEL BEAM TO CONCRETE-FILLED SQUARE STEEL TUBE COLUMN MOMENT CONNECTIONS}

- Simple model of load-deformation relations for connection details using internal diaphragms or internal diaphragms with extended flanges -

\section{福 元 敏之*}

\section{Toshiyuki FUKUMOTO}

\begin{abstract}
This paper proposes a new simple model for a load-displacement relation for predicting the local tensile elasto-plastic behavior of concrete filled square steel tube (CFT) column to steel beam moment connections using internal diaphragms or internal diaphragms with extended flanges. This model is developed by superposing the load-deformation relations of a tube flange and web. The tube flange is modeled as a grid beam with a tetra-linear load-deformation relation, while the tube web is modeled as a tensile member with a tetra-linear load-deformation relation. The strength of the internal diaphragm is superposed to the strength of these tube load-deformation models. The analytical results agree approximately with the experimental results up to large deformations.
\end{abstract}

\section{Keywords : Beam-to-column connection, Concrete-filled square steel tube column, Steel beam, Internal diaphragm (with extended flange), Load-displacement relation 柱梁接合部、コンクリート充填角形鋼管柱、鉄骨梁、内 $($ 通し ) ダイアフラム、荷重-変形関係}

\section{1 序 論}

コンクリート充填角形鋼管柱（以下角形 CFT 柱と呼ぶ）と鉄骨梁 とを組み合わせた混合構造が、現状、事務所ビル等で多用されている。 斯かる柱梁接合部には、図 I に示す鋼管内部に補強材を設置した内部 補強形式として、内ダイアフラム形式と通しダイアフラム形式があ る。柱梁接合部の把握すべき主な構造性状としては、接合部パネルの 性状と、鉄骨梁フランジから接合部パネルへの応力伝達に関する接合 部局部の性状が挙げられる。これらの接合部局部の耐力評価式は、鉄 骨鉄筋コンクリート構造計算規準・同解説」 ${ }^{1)}$ の解説に提示されてい るが、今後の構造性能規定型設計法の導入を鑑みると、耐力評価のみ ならず、接合部の弾塑性性状を予測する荷重-変形関係モデルの構築 が肝要である。著者等 ${ }^{2), 3)}$ は、これ迄、上述の内部補強形式接合部局 部に関する荷重一変形関係モデルを提案している。提案のモデルは、 鋼管フランジを格子梁に、鋼管ウェブを引張材に置換すると共に、ダ イアフラムを斜めの引張材に置換し、荷重一変形関係を求めるもので、 梁幅と柱幅の比 ( 以下、梁柱幅比と呼ぶ ) を考慮して、二種類の耐荷 機構を考えている。しかし、斯かるモデルは、二種類の耐荷機構につ いて、各抵抗要素の荷重一変形曲線を累加し、柱梁接合部局部の荷重 一変形関係を求める為、計算が煩雑であり、実用に資するには、簡易 化された荷重一変形関係モデルの案出が必要である。他面、河野等 ${ }^{4}$ は、内ダイアフラム形式及び通しダイアフラム形式を対象に、接合部 局部引張実験結果及び弾塑性有限要素法解析結果を基に、統計的に求 めた簡便な荷重一変形関係モデルを提案しているが、モデル構築に於 いて、梁幅が柱幅に近い場合のデー夕は含まれていない。 そこで、本研究では、内部補強形式の角形 CFT 柱梁接合部局部の

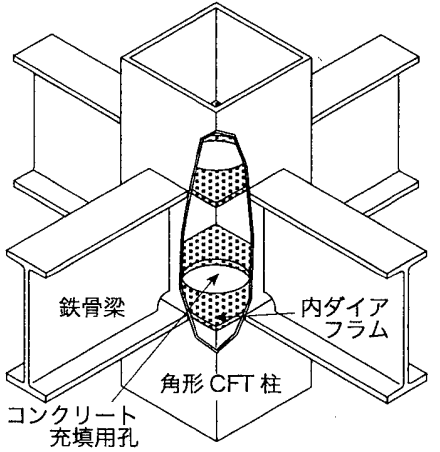

(a) 内ダイアフラム形式

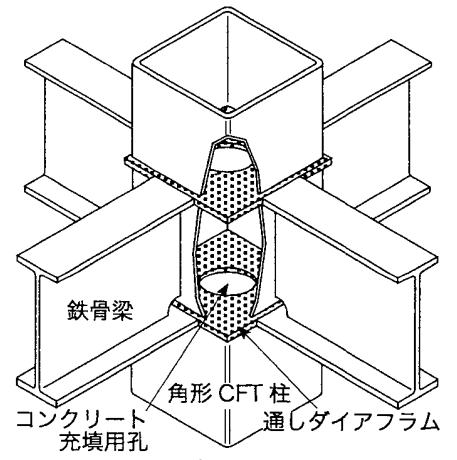

(b) 通しダイアフラム形式
图 1 角形 CFT 柱・鉄骨梁接合部

簡易な荷重一変形関係モデルを構筑することを目的に、一つの耐荷機 構モデルで広範囲な梁柱幅比に対応すると共に、モデルの計算に於け る簡易化を図った荷重一変形関係モデルを提案する。本論文では、提 案の荷重一変形関係モデル及び既往の実験資料と本モデルとの比較検 討について論及する。

\section{2 荷重-变形関係モテル}

\section{1 モテル概要}

本モデルは、内部補強形式角形 CFT 柱・鉄骨梁接合部局部を対象 に、鋼管を図 2 及び図 3 に示す如く、フランジを格子梁に、ウェブを 引張材に、他方、内ダイアフラム及び通しダイアフラムを、図 4 に示 す如く、斜め引張斜材に置換している。ダイアフラムは、A 部分と B 部分に分けて考え、A 部分は、梁フランジから直接に力を受ける部分 
であり、B 部分は、A 部分と柱鋼管の強制変形によって耐力を発揮す る部分と考えている。これらの各要素のモデル化は、前報 ${ }^{21,3)}$ と同一 であるが、本論のモデルは、鋼管の格子梁を材軸方向と周方向に分け、 鋼管格子梁周方向と鋼管ウェブの引張材を連結し、梁柱幅比の変化に 対して一つのモデルで評価できることが特徴である。尚、鋼管のフラ ンジ格子梁とウェブ引張材の荷重一変形関係は図 5 である。これらよ り、本モデルは、鋼管フランジ材軸方向梁の荷重一変形関係又は鋼管 フランジ周方向梁とウェブ引張材の周方向連結部材に依る鋼管の荷重 一変形関係を求め、その各点にダイアフラムの耐力を累加し、図 6 に 示す柱梁接合部局部の荷重-変形関係を求めるものである。又、鋼管 の格子梁に関して、前報 ${ }^{2)}$ 3) では、変形算出式が複雑であり、実用性 に欠けることから、本研究では簡易式を案出した。

以下に、鋼管格子梁の有効スパン及び鋼管とダイアフラムの荷重一 変形関係モデルについて言及する。

\section{2 鋼管フランジ格子梁の有効スパン}

鋼管格子梁のスパン $(y$ 、図 3 参照 $)$ を求める為、梁フランジに荷重 $(P)$ が作用し時、変形 $(\boldsymbol{\delta})$ が生じるとして、外部仕事と鋼管フランジ及び ダイアフラムによる内部仕事とを同一とする仮想仕事の原理を準用す ると、(1) 式となる。ここで、鋼管フランジは、材軸方向梁及び周方 向梁の全塑性状態を、鋼管ウェブは図 3(b) の全塑性状態を想定して いる。又、ダイアフラムは後述する A 部分と B 部分が降伏する全塑 性状態を想定している。尚、(1) 式に於いて、鋼管周方向梁とウェブ 引張材が直列に連結されている為、各々の変形 $\left(\right.$ 各々 $\left.{ }_{x} \boldsymbol{\delta},{ }_{w} \boldsymbol{\delta}\right)$ を求め る必要がある。これらのフランジ周方向梁、ウェブ引張材の変形の糸
加が、(2) 式の如く変形 $(\boldsymbol{\delta})$ となり、変形 $(\delta)$ に対する周方向梁、引張 材の変形の比率 (各々 ${ }_{x} a,{ }_{w} a$ ) は、(4) 式及び (5) 式に依る全塑性時の 割線剛性 (各々 ${ }_{x} k,{ }_{w} k$ ) に基づき、(3) 式となり、これらを(1) 式に適 用する。全塑性時の割線剛性を求める際の全塑性時の変形は、フラン ジ周方向梁に関して、弾性剛性に形状係数 $(f)$ 及び降伏変形に対する 変形倍率 $\left(a_{p 、}\right.$ (16a) 式参照) を勘案し求めると共に、鋼管ウェブに関 しては、後述する降伏変形の 2 倍とした。

周方向スパン $\left.{ }_{x} l\right)$ は幾何学的に求まり、(6) 式となる。又、材軸方 向スパン $\left.{ }_{y} l\right)$ は、 $P$ を最小とする条件 $\frac{\partial P}{\partial y}=0$ より、(7) 式を得る。尚、 スパン $\left.{ }_{y} l\right)$ を求める際、解が複雑になり、実用性に供しない面から、 ${ }_{y} l$ に比較して ${ }_{r} t$ が小さいので、, $t=0$ として、(7) 式を求めた。

$$
\begin{aligned}
& P \cdot \delta=4\left({ }_{x} M_{p} \cdot{ }_{x} a \cdot{ }_{x} \theta+{ }_{y} M_{p} \cdot{ }_{y} \theta\right)+2\left({ }_{r} t+2 \frac{y^{l}}{2} \frac{2}{3}\right){ }_{c} t \cdot{ }_{c} \sigma_{y} \cdot{ }_{n} a \cdot \delta \\
& +\frac{2}{\sqrt{2}}\left({ }_{d} W_{A}+\frac{{ }_{d} W_{B}}{2}\right){ }_{d} t \cdot{ }_{d} \sigma_{y} \cdot \delta \\
& { }_{x} M_{p}={ }_{x} Z_{p} \cdot{ }_{c} \sigma_{y}=\frac{\left(2{ }_{y} l+{ }_{r} t\right){ }_{c} t^{2}}{4}{ }_{c} \sigma_{y} 、{ }_{x} \theta=\frac{\delta}{{ }_{x} l} \\
& { }_{y} M_{p}={ }_{y} Z_{p} \cdot{ }_{c} \sigma_{y}=\frac{\left(D-{ }_{c} t\right){ }_{c} t^{2}}{4}{ }_{c} \sigma_{y} 、{ }_{y} \theta=\frac{\delta}{{ }_{y} l} \\
& \delta={ }_{x} \delta+{ }_{w} \delta={ }_{x} a \cdot \delta+{ }_{w} a \cdot \delta \\
& { }_{x} a=\frac{{ }_{x} \delta}{{ }_{x} \delta+{ }_{w} \delta}=\frac{1}{1+\frac{{ }_{x} k}{{ }_{w} k}},{ }_{w} a=\frac{{ }_{w} \delta}{{ }_{x} \delta+{ }_{w} \delta}=\frac{1}{1+\frac{{ }_{w} k}{{ }_{x} k}} \\
& { }_{x} k=\frac{\left(2{ }_{y} l+{ }_{r} t\right){ }_{c} t^{3} \cdot{ }_{s} E}{{ }_{x} l^{3}} \frac{f}{a_{p}}
\end{aligned}
$$

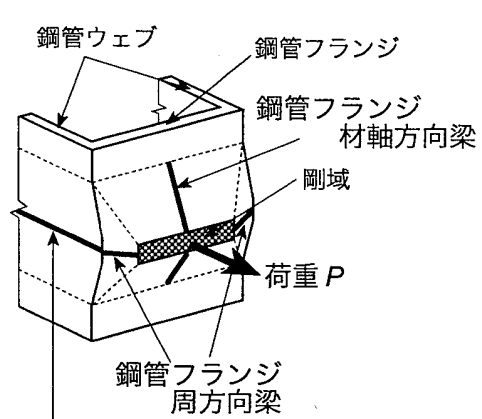

鋼管ウェブ引張材

図 2 鋼管のモテル

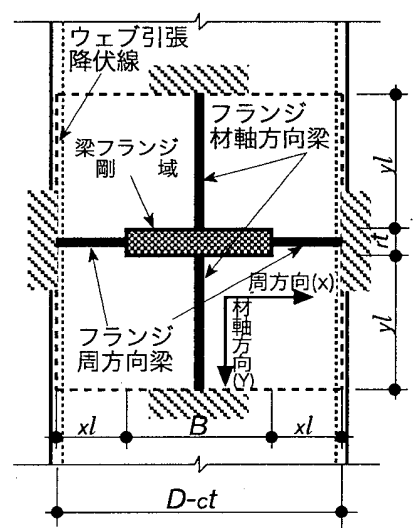

(a) 鋼管フランジの格子梁

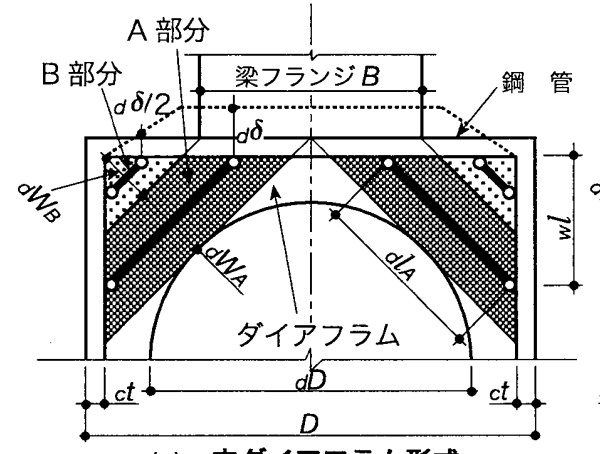

(a) 内ダイアフラム形式

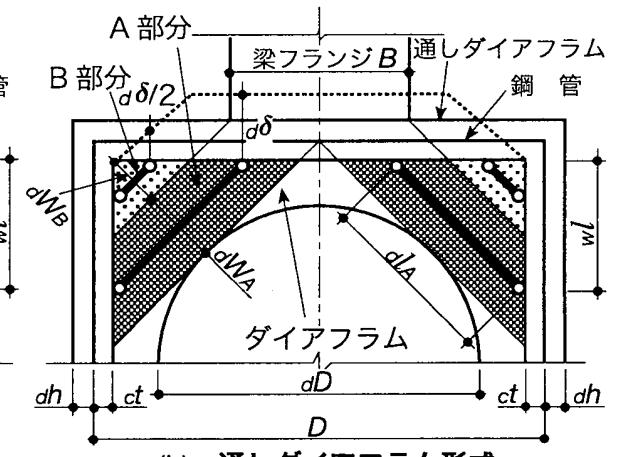

(b) 通しダイアフラム形式

図 4 ダイアフラムのモテル

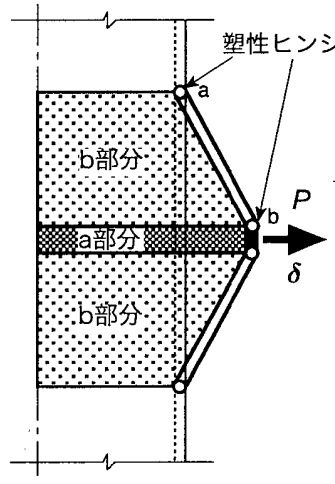

降伏及び全塑性耐力点の 応力状態

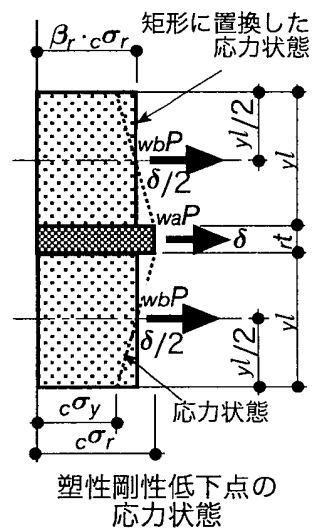

応力状態

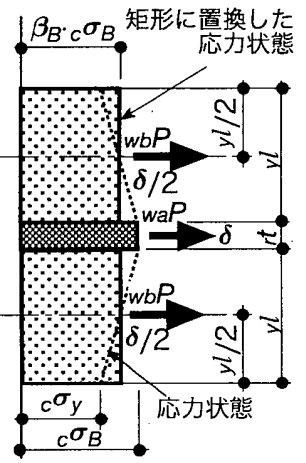

最大耐力点の 応力状態 


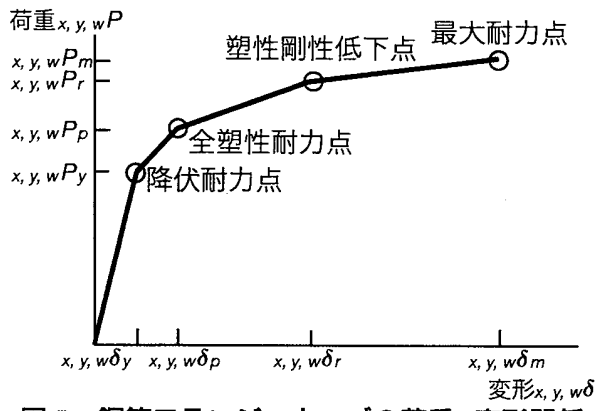

図 5 鋼管フランジ・ウェブの荷重-変形関係

$$
\begin{aligned}
& f=\frac{Z_{p}}{Z} \\
& { }_{w} k=\frac{\left({ }_{r} t+\frac{2{ }_{y} l}{3}\right){ }_{c} t \cdot{ }_{c} \sigma_{y}}{\frac{D \cdot{ }_{c} \sigma_{y}}{2{ }_{s} E}} \frac{1}{2}=\frac{\left({ }_{r} t+\frac{2 y}{3} l\right){ }_{c} t \cdot{ }_{s} E}{D} \\
& { }_{x} l=\frac{D-{ }_{c} t-B}{2} \\
& l=\sqrt{\frac{\left(D-{ }_{c} t\right)\left(95{ }_{x} l^{3}+81 D \cdot{ }_{c} t^{2}\right)}{190{ }_{x} l^{2}+108 D \cdot{ }_{c} t}}
\end{aligned}
$$

$a_{p}$ : 格子梁の降伏耐力点変形に対する各々全塑性耐力点の変 形の倍率((16a)式参照)、 $B$ : 梁幅(図3参照)、 $D$ : 鋼管径、 ${ }_{s} E$ : 鋼材のヤング率、 $f:$ 形状係数、 ${ }_{x} k,{ }_{w} k:$ 周方向梁及びウェブの 割線剛性、 ${ }_{x} l, y$, : 鋼管フランジ格子梁スパン(図3参照)、 ${ }_{x} M_{p}$ : 周方向梁の全塑性モーメント、 ${ }_{y} M_{p}$ : 材軸方向梁の全塑性モー メント、 ${ }_{c} t$ : 鋼管板厚、 $d t$ : ダイアフラム板厚、 ${ }_{r} t$ : 溶接余盛を 含む梁フランジ板厚(図3参照)、 ${ }_{d} W_{A},{ }_{d} W_{A}:$ ダイアフラム斜め引 張材の有効幅(図4, (30)式参照)、 $Z$ : 断面係数、 $Z_{p}$ : 塑性断面係 数、 ${ }_{x} Z_{p}$ : 周方向梁の塑性断面係数、 $Z_{p}$ : 材軸方向梁の塑性断 面係数、 ${ }_{x} \delta,{ }_{w} \delta$ : 周方向梁及びウェブの変形、 ${ }_{x} \theta,{ }_{y} \theta:$ 格子梁の 変形角、 ${ }_{c} \sigma_{y}$ : 鋼管材料の降伏点、 $d \sigma_{y}:$ ダイアフラムの降伏点

\section{3 鋼管の荷重-変形関係}

\section{(1) フランジ材軸方向}

鋼管フランジ材軸方向梁 ( 図 3(a) 参照) の荷重 $\left({ }_{y} P\right)$-変形 $\left.{ }_{y} \delta\right)$ 関係 は、梁の曲げ変形のみ考え、文献 2) に於ける図 7 の鋼材の応力度-歪 度関係に基づく梁の曲げモーメント-曲率関係から、図 5 に示す降伏 耐力点 $\left({ }_{y} P_{y} 、 y \delta_{y}\right)$ 、全塑性耐力点 $\left({ }_{y} P_{p} 、{ }_{y} \delta_{p}\right)$ 、塑性剛性低下点 $\left({ }_{y} P_{r} 、 y \delta_{r}\right)$ 及び最大耐力点 $\left({ }_{y} P_{m}, y \delta_{m}\right)$ の tetra-linear 型にモデル化したものである 2),3)。材軸方向梁のスパンは (7) 式で、各点の耐力と変形は (8) 式〜 (11) 式で得られる。

前報 ${ }^{2), 3)}$ では、全塑性耐力点、塑性剛性低下点及び最大耐力点に於 ける降伏耐力時に対する変形倍率 (各々 $a_{p}, a_{r}, a_{m}$ ) は、曲げ変形に基 づき (13) 式に依って求めているが、格子梁が長方形断面であり、形 状係数 $f=3 / 2$ 、降伏時に対する全塑性時曲率倍率 $n=10$ (全塑性耐力に ほぼ達する倍率)を(13) 式に代入すると、全塑性耐力点及び塑性剛性 低下点の変形倍率式は簡便になるが、最大耐力点の変形倍率式は複雑 であり、実用性にそしいことから、表 2 の各因子デー夕に依る (13c) 式の計算值を各因子に基づき回帰式を(15) 式の如く作成した。最大

最大耐力点

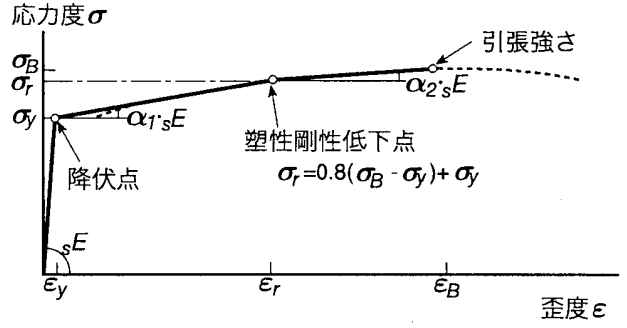

図 7 鋼材の応力度-歪度モデ

表 1 鋼材剛性低下率式の係数

\begin{tabular}{c|c|c|c|c}
\hline \multirow{2}{*}{ 鋼 種 } & \multicolumn{2}{|c|}{ 第1剛性低下率 $\boldsymbol{\alpha}_{\mathrm{r}}$} & \multicolumn{2}{c}{ 第2剛性低下率 $\boldsymbol{\alpha}_{2}$} \\
\cline { 2 - 5 } & $\mathrm{C}_{11}$ & $\mathrm{C}_{10}$ & $\mathrm{C}_{21}$ & $\mathrm{C}_{20}$ \\
\hline $400 \mathrm{~N} / \mathrm{mm}^{2}$ 鋼 & -0.0102 & 0.0147 & -0.00164 & 0.00239 \\
\hline $500 \mathrm{~N} / \mathrm{mm}^{2}$ 鋼 & -0.0262 & 0.0281 & -0.00757 & 0.00772 \\
\hline $600 \mathrm{~N} / \mathrm{mm}^{2}$ 鋼 & -0.0473 & 0.0502 & -0.00292 & 0.00429 \\
\hline $800 \mathrm{~N} / \mathrm{mm}^{2}$ 鋼 & -0.2170 & 0.2120 & -0.02220 & 0.02290 \\
\hline
\end{tabular}

耐力点 $\left(a_{m}\right)$ に関して、(13c) 式の精算値と (15) 式の略算値の比較を図 8 に示す。精算値 / 略算値の值は、0.73〜 1.18( 平均值 0.98 、変動係 数 0.013$)$ と、略算值は精算値をほぼ推定していると言える。依って、 形状係数 $f=3 / 2$ 、降伏時に対する全塑性時曲率倍率 $n=10$ を (13a) 式、 (13b) 式及び (15) 式に代入すると、(16) 式となる。尚、鋼材の剛性低 下率は、文献 2)により (14) 式となる。

\section{[降伏耐力点]}

$$
{ }_{y} P_{y}=\frac{2\left(D-{ }_{c} t\right){ }_{c} t^{2}}{3{ }_{y} l}{ }_{c} \sigma_{y} 、{ }_{y} \delta_{y}=\frac{{ }_{c} \sigma_{y} \cdot{ }_{y} l^{2}}{3{ }_{c} t \cdot{ }_{s} E}
$$

\section{[全塑性耐力点]}

$$
{ }_{y} P_{p}=\frac{\left(D-{ }_{c} t\right){ }_{c} t^{2}}{{ }_{y} l}{ }_{c} \sigma_{y}=\frac{3}{2}{ }_{y} P_{y} 、{ }_{y} \delta_{p}=a_{p} \cdot{ }_{y} \delta_{y}
$$

[塑性剛性低下点]

$$
{ }_{y} P_{r}=\frac{\left(D-{ }_{c} t\right){ }_{c} t^{2}}{{ }_{y} l}{ }_{c} \sigma_{r}=\frac{{ }_{y} P_{p}}{Y^{\prime}} 、{ }_{y} \delta_{r}=a_{r} \cdot{ }_{y} \delta_{y}
$$

\section{[最大耐力点]}

$$
\begin{aligned}
& { }_{y} P_{m}=\frac{\left(D-{ }_{c} t\right){ }_{c} t^{2}}{{ }_{y} l}{ }_{c} \sigma_{B}=\frac{{ }_{y} P_{p}}{Y} 、{ }_{y} \delta_{m}=a_{m} \cdot{ }_{y} \delta_{y} \\
& Y=\frac{\sigma_{y}}{\sigma_{B}}, Y^{\prime}=\frac{\sigma_{y}}{\sigma_{r}} \\
& a_{p}=\frac{\delta_{p}}{\delta_{y}}=\frac{1}{f^{2}}+\frac{f}{C}\left(1-\frac{1}{f^{3}}\right)+\frac{3}{2 C}(C-1)\left(1-\frac{1}{f^{2}}\right) \\
& a_{r}=\frac{\delta_{r}}{\delta_{y}}=\left(\frac{Y^{\prime}}{f}\right)^{2}+\frac{f \cdot Y^{12}}{C}\left(1-\frac{1}{f^{3}}\right)+\frac{3 Y^{12}}{2}\left(1-\frac{1}{C}\right)\left(1-\frac{1}{f^{2}}\right) \\
& +\frac{f}{\alpha_{1} \cdot Y^{\prime}}\left(1-Y^{\prime 3}\right)+\frac{3}{2}\left(n-\frac{f}{\alpha_{1}}\right)\left(1-Y^{\prime 2}\right) \\
& a_{m}=\frac{\delta_{m}}{\delta_{y}}=\left(\frac{Y}{f}\right)^{2}+f\left\{\frac{Y^{2}}{C}\left(1-\frac{1}{f^{3}}\right)+\frac{Y^{2}}{\alpha_{1}}\left(\frac{1}{Y^{13}}-1\right)\right. \\
& \left.+\frac{1}{\alpha_{2} \cdot Y}\left(1-\frac{Y^{3}}{Y^{13}}\right)\right\}+\frac{3}{2}\left\{Y^{2}\left(1-\frac{1}{C}\right)\left(1-\frac{1}{f^{2}}\right)\right. \\
& \left.+Y^{2}\left(n-\frac{f}{\alpha_{1}}\right)\left(\frac{1}{Y^{\prime 2}}-1\right)+\left(n_{r}-\frac{f}{\alpha_{2} \cdot Y^{1}}\right)\left(1-\frac{Y^{2}}{Y^{\prime 2}}\right)\right\} \\
& C=\frac{f-1.0}{n-1.0} 、 n_{r}=\frac{f}{\alpha_{1}}\left(\frac{1}{Y^{\prime}}-1\right)+n
\end{aligned}
$$


表 2 簡易変形倍率式作成に 用いたデータ範囲

\begin{tabular}{c|c}
\hline 因 & 範 \\
\hline 形状係数 $(f)$ & $1.1 \sim 2.0$ \\
\hline $\begin{array}{c}\text { 降伏時に対する全塑性 } \\
\text { 時の曲率倍率 }(n)\end{array}$ & $5 \sim 19$ \\
\hline 鋼材降伏比 $(Y)$ & $0.50 \sim 0.97$ \\
\hline $\begin{array}{c}\text { 塑性剛性低下点に関す } \\
\text { る降伏比 }\left(Y^{\prime}\right)\end{array}$ & $0.56 \sim 0.98$ \\
\hline 第1剛性低下率 $\left(\alpha_{1}\right)$ & $0.00151 \sim 0.04274$ \\
\hline 第2剛性低下率 $\left(\alpha_{2}\right)$ & $0.000996 \sim 0.005584$ \\
\hline
\end{tabular}

$\alpha_{1}=c_{11} \frac{\sigma_{y}}{\sigma_{B}}+c_{10} 、 \alpha_{2}=c_{21} \frac{\sigma_{y}}{\sigma_{B}}+c_{20}$

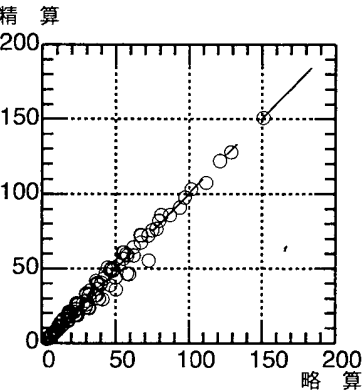

図 8 最大耐力点の変形倍率 精算値と略算値の比較

$a_{m}=\frac{0.8 f^{1.73}}{{\alpha_{2}}^{0.5} \cdot Y^{4.34}}\{f(Y-0.79)(Y-0.26)-2.9(Y-0.95)(Y-0.29)\}$

$a_{p}=\frac{95}{18}$

$a_{r}=\frac{3\left(Y^{\prime 3}-3 Y^{\prime}+2\right)}{4 \alpha_{1} \cdot Y^{\prime}}-\frac{175 Y^{\prime 2}}{18}+15$

$a_{m}=\frac{2.28}{\alpha_{2}^{0.5} \cdot Y^{4.34}}(1.14-Y)(Y-0.31)$

$a_{p}, a_{r}, a_{m}$ : 格子梁の降伏耐力点の変形に対する各々全塑性耐 力点、塑性剛性低下点及び最大耐力点の変形の倍率、 $\mathrm{C}_{11}, \mathrm{C}_{10}$, $\mathrm{C}_{21}, \mathrm{C}_{20}$ : 表1参照、 $n=10$ : 降伏時に対する全塑性時曲率倍率、 $Y:$ 降伏比(降伏点/引張強さ)、 $Y^{\prime}:$ 塑性剛性低下点忘力度(図 7参照)に対する降伏点(降伏点/塑性剛性低下点応力度)、 $\alpha_{l}$, $\alpha_{2}$ : 鋼材の第1、第2剛性低下率(図7、(14)式参照)、 $\sigma_{y}, \sigma_{B}$ : 鋼 材の降伏点、引張強さ、 ${ }_{c} \sigma_{y},{ }_{c} \sigma_{r, c} \sigma_{B}:$ 鋼管材料の降伏点、塑 性剛性低下点応力度(図7参照)、引張強さ

\section{(2) フランジ周方向}

鋼管フランジ周方向梁の梁スパン $\left.{ }_{x} l\right)$ は (6) 式で与えられる。荷重 $\left.{ }_{x} P\right)$ 一変形 $\left.{ }_{x} \delta\right)$ 関係は、材軸方向と同様に、図 5 に示す降伏耐力点 ${ }_{x} P_{y}$ 、 $\left.{ }_{x} \boldsymbol{\delta}_{y}\right)$ 、全塑性耐力点 $\left({ }_{x} P_{p} 、{ }_{x} \boldsymbol{\delta}_{P}\right)$ 、塑性剛性低下点 $\left({ }_{x} P_{r} 、{ }_{x} \boldsymbol{\delta}_{r}\right)$ 及び最大耐 力点 $\left({ }_{x} P_{m 、 x} \delta_{m}\right)$ の tetra-linear 型モデルである。各点の耐力と変形は (17) 式〜 (20) 式となる。

\section{[降伏耐力点]}

$$
{ }_{x} P_{y}=\frac{2\left(2{ }_{y} l+{ }_{r} t\right){ }_{c} t^{2}}{3_{x} l}{ }_{c} \sigma_{y} 、{ }_{x} \delta_{y}=\frac{{ }_{c} \sigma_{y} \cdot{ }_{x} l^{2}}{3_{c} t \cdot{ }_{s} E}
$$

\section{[全塑性耐力点]}

$$
{ }_{x} P_{p}=\frac{\left(2{ }_{y} l+{ }_{r} t\right){ }_{c} t^{2}}{{ }_{x} l}{ }_{c} \sigma_{y}=\frac{3}{2}{ }_{x} P_{y} 、{ }_{x} \delta_{p}=a_{p} \cdot{ }_{x} \delta_{y}
$$

\section{[塑性剛性低下点]}

$$
{ }_{x} P_{r}=\frac{\left(2{ }_{y} l+{ }_{r} t\right){ }_{c} t^{2}}{{ }_{x} l}{ }_{c} \sigma_{r}=\frac{{ }_{x} P_{p}}{Y^{\prime}} 、{ }_{x} \delta_{r}=a_{r} \cdot{ }_{x} \delta_{y}
$$

[最大耐力点]

$$
{ }_{x} P_{m}=\frac{\left(2, l+{ }_{r} t\right){ }_{c} t^{2}}{{ }_{x} l}{ }_{c} \sigma_{B}=\frac{{ }_{x} P_{p}}{Y} 、{ }_{x} \delta_{m}=a_{m} \cdot{ }_{x} \delta_{y}
$$

\section{（3）鋼管ウェブの荷重-変形関係}

前報 ${ }^{2,3)}$ (゙は、鋼管ウェブの荷重-変形関係を tri-linear 型モデルと したが、本論では、鋼管フランジ周方向と連結することを考慮する為、
鋼管ウェブの荷重 $\left.{ }_{w} P\right)$-変形 $\left.{ }_{w} \boldsymbol{\delta}\right)$ 関係は、図 5 に示す降伏耐力点 $\left({ }_{w} P_{y}\right.$ 、 $\left.{ }_{w} \delta_{y}\right)$ 、全塑性耐力点 $\left({ }_{w} P_{p} 、{ }_{w} \delta_{p}\right)$ 、塑性剛性低下点 $\left({ }_{w} P_{r} 、{ }_{w} \delta_{r}\right)$ 及び最大耐 力点 $\left({ }_{w} P_{m} 、{ }_{w} \delta_{m}\right)$ の tetra-linear 型の引張抵抗モデルとする。これらの 各点での引張抵抗 (図 3(b) 参照) は、変形状態を鑑みて、変形が微少 である降伏耐力点では $\mathrm{a}$ 部分のみ抵抗して、鋼材の降伏点に達した時 とし、以降は $a$ 部分と $b$ 部分の抵抗を考える。全塑性耐力点では、 $b$ 部分が抵抗し始める変形レベルと考え、 $\mathrm{b}$ 部分を三角形の応力分布と し、 $\mathrm{a}$ 点で灾力が無く、 $\mathrm{b}$ 点で鋼材の降伏点に達する応力状態を想定 する。塑性剛性低下点及び最大耐力点では、 $\mathrm{b}$ 点が各々鋼材の塑性剛 性低下点 (図 7 参照) 及び引張強さに達した時とし、塑性剛性低下点 及び最大耐力点では変形が可成り大きいことを鑑みて、a 点を鋼材の 降伏点とし、計算の簡便化を図り、 $\mathrm{b}$ 部分はこれらの応力度の平均に よる矩形分布とする。

降伏耐力点 $\left({ }_{w} P_{y} 、{ }_{w} \delta_{y}\right)$ は、 $\mathrm{a}$ 部分のみ抵抗し、鋼材の降伏点に達し た時で、変形は鋼管ウェブが一様に変形するとし、(21) 式となる。

\section{[降伏耐力点]}

$$
\begin{aligned}
& { }_{w} P_{y}=2\left({ }_{r} t \cdot{ }_{c} t \cdot{ }_{c} \sigma_{y}+{ }_{d} h \cdot{ }_{d} t \cdot{ }_{d} \sigma_{y}\right) 、 \\
& { }_{w} \delta_{y}=\frac{D}{2}{ }_{c} \varepsilon_{y}=\frac{D \cdot{ }_{c} \sigma_{y}}{2{ }_{s} E}
\end{aligned}
$$

${ }_{d} h:$ 通しダイアフラムの鋼管よりの出寸法(図4参照)、 ${ }_{c} \varepsilon_{y}:$ 鋼 管材料の降伏点の歪度

全塑性耐力は、 $\mathrm{a}$ 部分と三角形分布の $\mathrm{b}$ 部分の応力状態を仮定し、 仮想仕事の原理を準用して外部仕事と $\mathrm{a}$ 部分及び $\mathrm{b}$ 部分による内部仕 事を同一とすると (22) 式となり、(23) 式の全塑性耐力 $\left.{ }_{w} P_{p}\right)$ が求まる。 又、変形 $\left(_{w} \delta_{p}\right)$ は、降伏耐力点以降、更に $\mathrm{b}$ 部分が降伏に達する時と して、降伏変形の 2 倍とした。

$$
{ }_{w} P_{p} \cdot \delta=2\left\{\left({ }_{r} t \cdot \delta+2 \frac{1}{2}{ }_{y} l \cdot \frac{2 \delta}{3}\right){ }_{c} t \cdot{ }_{c} \sigma_{y}+{ }_{d} h \cdot{ }_{d} t \cdot{ }_{d} \sigma_{y} \cdot \delta\right\}
$$

\section{[全塑性耐力点]}

$$
\begin{aligned}
& { }_{w} P_{p}=2\left\{\left({ }_{r} t+\frac{2}{3}{ }_{y} l\right){ }_{c} t \cdot{ }_{c} \sigma_{y}+{ }_{d} h \cdot{ }_{d} t \cdot{ }_{d} \sigma_{y}\right\} 、 \\
& { }_{w} \delta_{p}=2{ }_{w} \delta_{y}
\end{aligned}
$$

塑性剛性低下点耐力は、図3(b) の応力状態を仮定し、仮想仕事の 原理を用いて、外部仕事と $\mathrm{a}$ 部分及び $\mathrm{b}$ 部分による内部仕事を同一と すると (24) 式となり、(25) 式の塑性剛性低下点耐力 $\left.{ }_{w} P_{r}\right)$ が求まる。 他方、変形は、塑性剛性低下点では塑性化が進み、梁フランジ近傍の 変形が集中すると考元、梁フランジ側で塑性剛性低下点歪度に達し、 徐々に歪度が減少し、後述のダイアフラム $\mathrm{A}$ 部分の支点までの距離 ( ${ }_{w} l$, 図 4 参照) の点で歪度が無くなる三角形の歪度分布を仮定して、変形 を求めると $(25)$ 式の塑性剛性低下点耐力 $\left.{ }_{w} \boldsymbol{\delta}_{r}\right)$ となる。

$$
\begin{aligned}
{ }_{w} P_{r} \cdot \delta & =2\left\{\left\{{ }_{r} t \cdot \delta+2 \beta_{r} \cdot{ }_{y} l \cdot \frac{\delta}{2}\right){ }_{c} t \cdot{ }_{c} \sigma_{r}+{ }_{d} h \cdot{ }_{d} t \cdot{ }_{d} \sigma_{r} \cdot \delta\right\} \cdots \cdots \cdots \\
\beta_{r} & =\frac{{ }_{c} \sigma_{r}+{ }_{c} \sigma_{y}}{2{ }_{c} \sigma_{r}}=\frac{1+Y^{\prime}}{2} \\
{ }_{d} \sigma_{r} & : \text { ダイアフラムの塑性剛性低下点の応力度(図7参照) }
\end{aligned}
$$

[塑性剛性低下点]

$$
\begin{aligned}
& { }_{\mathrm{w}} P_{r}=2\left\{\left({ }_{r} t+\beta_{r} \cdot{ }_{y} l\right){ }_{c} t \cdot{ }_{c} \sigma_{r}+{ }_{d} h \cdot{ }_{d} t \cdot{ }_{d} \sigma_{r}\right\} 、 \\
& { }_{w} \delta_{r}=\int_{0}^{{ }_{n} l}{ }_{c} \varepsilon_{r} \frac{x}{{ }_{w} l} \mathrm{~d} x=\frac{{ }_{d} l_{A}}{2 \sqrt{2}}{ }_{c} \varepsilon_{r}
\end{aligned}
$$


${ }_{n} l=\frac{{ }_{d} l_{A}}{\sqrt{2}}$

${ }_{d} l_{A}:$ ダイアフラム引張ブレースAの長さ(図4参照)、w $l:$ 図 4 参

照、 $\varepsilon_{r}:$ 鋼管材料の塑性剛性低下点の歪度

最大耐力点は、塑性剛性低下点と同様に、耐力、変形を求めると (27) 式となる。

\section{[最大耐力点]}

${ }_{w} P_{m}=2\left\{\left({ }_{r} t+\beta_{B} \cdot{ }_{y} l\right){ }_{c} t \cdot{ }_{c} \sigma_{B}+{ }_{d} h \cdot{ }_{d} t \cdot{ }_{d} \sigma_{B}\right\}$.

${ }_{w} \delta_{m}=\frac{{ }_{d} l_{A}}{2 \sqrt{2}}{ }_{c} \varepsilon_{B}$

$\beta_{B}=\frac{{ }_{c} \sigma_{B}+{ }_{c} \sigma_{y}}{2{ }_{c} \sigma_{B}}=\frac{1+Y}{2}$

${ }_{c} \boldsymbol{\varepsilon}_{B}:$ 鋼管材料の引張強さの歪度、 ${ }_{d} \boldsymbol{\sigma}_{B}:$ ダイアフラムの引張強 さ

\section{4 ダイアフラムの耐力}

前報 2), 3) では、ダイアフラムの荷重一変形関係を tri-linear 型モデル としたが、本論では、鋼管の荷重一変形関係に於ける各点に対応した 耐力とする為、降伏耐力 $\left({ }_{d} P_{y}\right)$ 、全塑性耐力 $\left({ }_{d} P_{p}\right)$ 、塑性剛性低下点耐 力 $\left.{ }_{d} P_{r}\right)$ 及び最大耐力 $\left.{ }_{d} P_{m}\right)$ を求める。ダイアフラムは、前述の如く、 $\mathrm{A}$ 部分と $\mathrm{B}$ 部分に分けて考える (図 4 参照)。尚、45 度方向の引張材 の梁材軸と直交方向の分力に関して、鋼管フランジ側では左右対称と なる引張材の分力が鈞り合い、鋼管ウェブ側では内部コンクリートに よって抵抗すると考える。ダイアフラムの耐力は、降伏耐力時には、 変形が小さく、 $\mathrm{A}$ 部分のみ耐力を発揮すると考えると、降伏耐力は (28) 式となる。他方、全塑性耐力、塑性剛性低下点耐力及び最大耐力は、 $\mathrm{A}$ 部分と $\mathrm{B}$ 部分の耐力が各々発揮されると想定する。全塑性時に於 いて、梁フランジの荷重 ${ }_{d} P_{p}$ に対して、梁材軸方向にダイアフラムが $\delta$ 変形すると仮定し、仮想仕事の原理を用いて外部仕事とダイアフラ ムによる内部仕事を同一とすると (29) 式となり、これより全塑性耐 力が (31) 式と得られる。同様に、塑性剛性低下点耐力及び最大耐力 を求めると、各々 (32) 式、(33) 式を得る。

\section{[降伏耐力]}

$$
\begin{aligned}
& { }_{d} P_{y}=\sqrt{2}{ }_{d} W_{A} \cdot{ }_{d} t \cdot{ }_{d} \sigma_{y} \\
& { }_{d} P_{p} \cdot \delta=2\left(\frac{1}{\sqrt{2}}{ }_{d} W_{A} \cdot \delta+\frac{1}{\sqrt{2}}{ }_{d} W_{B} \frac{\delta}{2}\right){ }_{d} t \cdot{ }_{d} \sigma_{y} \\
& { }_{d} W_{A}=\min \left(w_{A}^{\prime}, w_{A}^{\prime \prime}, w_{A}^{\prime \prime \prime}\right) 、{ }_{d} W_{B}=w_{A}^{\prime \prime}-{ }_{d} W_{A} \\
& w_{A}^{\prime}=\frac{1}{2 \sqrt{2}}\left(D+B+2{ }_{d} h-\sqrt{2}{ }_{d} D\right), \quad w_{A}^{\prime \prime}=\frac{1}{2}\left\{\sqrt{2}\left(D-2{ }_{c} t\right)-{ }_{d} D\right\} \\
& w_{A}^{\prime \prime \prime}=\sqrt{2}\left(\frac{B}{2}+{ }_{c} t+{ }_{d} h\right) \\
& { }_{d} D: \text { ダイアフラムの孔(図4参照)、 }{ }_{d} W_{A}{ }_{d} W_{B}: \text { ダイアフラム引張 } \\
& \text { ブレースA及びBの有効幅(図4参照) }
\end{aligned}
$$

\section{[全塑性耐力]}

$$
{ }_{d} P_{p}=\sqrt{2}\left({ }_{d} W_{A}+\frac{{ }_{d} W_{B}}{2}\right){ }_{d} t \cdot{ }_{d} \sigma_{y} \cdot
$$

\section{[塑性剛性低下点耐力]}

$$
{ }_{d} P_{r}=\sqrt{2}\left({ }_{d} W_{A}+\frac{{ }_{d} W_{B}}{2}\right){ }_{d} t \cdot{ }_{d} \sigma_{r}=\frac{{ }_{d} P_{p}}{Y^{\prime}}
$$

\section{[最大耐力]}

$$
{ }_{d} P_{m}=\sqrt{2}\left({ }_{d} W_{A}+\frac{{ }_{d} W_{B}}{2}\right){ }_{d} t \cdot{ }_{d} \sigma_{B}=\frac{{ }_{d} P_{p}}{Y}
$$

\section{5 接合部局部の荷重-変形関係}

柱梁接合部局部の荷重 $(P)$-変形 $(\delta)$ 関係は、図 6 に示す降伏耐力 点 $\left(P_{y} 、 \delta_{y}\right) 、$ 全塑性耐力点 $\left(P_{p} 、 \delta_{p}\right)$ 、塑性剛性低下点 $\left(P_{r} 、 \delta_{r}\right)$ 及び最 大耐力点 $\left(P_{m} 、 \delta_{m}\right)$ の tetra-linear 型モデルとする。各点の耐力は、鋼 管周方向梁とウェブ引張材の連結部材、鋼管材軸方向梁及びダイアフ ラムの耐力を累加する。他方、各点の変形は、周方向梁とウェブの連 結部材及び鋼管材軸方向梁の何れもが耐力を発揮する変形とし、何れ か大きい方の変形とする。図 9 は、鋼管周方向梁とウェブの連結部材 ( 周方向と図示) 及び鋼管材軸方向梁の変形比を、一般的に用いられ ている梁柱幅比 $\mathrm{B} / \mathrm{D}=0.33 \sim 1.00$ の範囲で示したものである。尚、こ こで用いたデー夕の鋼管の一般化幅厚比は $0.79 \sim 1.99$ である。斯か る図より、降伏耐力点では、鋼管周方向梁とウェブの連結部材 (周方 向部材 ) 及び鋼管材軸方向梁の何れの変形が大きくなるか定まらない が、全塑性耐力点、塑性剛性低下点及び最大耐力点では、鋼管材軸方 向梁の方が変形が大きくなっている。これらを鑑み、降伏耐力点の変 形は、鋼管材軸方向梁及び周方向連結部材の変形の大きい方とし、全 塑性耐力点、塑性剛性低下点及び最大耐力点の変形は、鋼管材軸方向 梁の変形を用いることとした。依って、各点の耐力と変形は、(34) 式 ～(37) 式となる。尚、周方向連結部材の降伏変形 $\left.{ }_{s} \delta_{y}\right)$ は、鋼管周方 向梁とウェブが連結されているので、各々の弾性剛性を用いて求めて いる。

\section{[降伏耐力点]}

$$
\begin{aligned}
& P_{y}={ }_{y} P_{y}+\min \left({ }_{x} P_{y},{ }_{w} P_{y}\right)+{ }_{d} P_{y} 、 \delta_{y}=\max \left({ }_{y} \delta_{y},{ }_{s} \delta_{y}\right) \cdots \cdots \cdots(34) \\
& { }_{s} \delta_{y}=\frac{\min \left({ }_{x} P_{y},{ }_{w} P_{y}\right)}{K_{y}}=\frac{\min \left({ }_{x} P_{y},{ }_{w} P_{y}\right)}{\left(\frac{1}{{ }_{x} K}+\frac{1}{{ }_{w} K}\right)^{-1}}=\min \left({ }_{x} P_{y},{ }_{w} P_{y}\right)\left(\frac{1}{{ }_{x} K}+\frac{1}{{ }_{w} K}\right) \\
& { }_{x} K=\frac{{ }_{x} P_{y}}{{ }_{x} \delta_{y}}{ }_{w} K=\frac{{ }_{w} P_{y}}{{ }_{w} \delta_{y}}
\end{aligned}
$$

${ }_{x} K,{ }_{w} K$ : 周方向梁及びウェブの弾性剛性、 ${ }_{x} P_{y},{ }_{x} \delta_{y}:(17)$ 式に依 る、 ${ }_{w} P_{y}{ }_{w} \delta_{y}:(21)$ 式に依る

\section{[全塑性耐力点]}

$$
\begin{aligned}
& P_{p}={ }_{y} P_{p}+\min \left({ }_{x} P_{p},{ }_{w} P_{p}\right)+{ }_{d} P_{p} 、 \delta_{p}={ }_{y} \delta_{p} \\
& \text { [塑性剛性低下点] }
\end{aligned}
$$

$$
P_{r}={ }_{y} P_{r}+\min \left({ }_{x} P_{r},{ }_{w} P_{r}\right)+{ }_{d} P_{r} 、 \delta_{r}={ }_{y} \delta_{r}
$$

[最大耐力点]

$$
P_{m}={ }_{y} P_{m}+\min \left({ }_{x} P_{m},{ }_{w} P_{m}\right)+{ }_{d} P_{m} 、 \delta_{m}={ }_{y} \delta_{m}
$$

\section{3 モデと実験資料の比較検討}

\section{1 荷重一変形関係}

実験結果と本モデルの比較検討に用いた実験資料は、文献 3) 〜文 献 6) に依る内ダイアフラム形式及び文献 3) 〜文献 4) に依る通しダイ アフラム形式の角形 CFT 柱・鉄骨梁接合部局部の引張実験結果の内、 荷重一変形関係が記載されている試験体を対象とした。以下の実験 結果の降伏耐力は、図 10 に示す荷重一変形関係の接線剛性が初期剛! 性の $1 / 3$ になる時の耐力より求める Slope Factor 法に依った。実験結 果と荷重一変形関係モデルの比較を、内ダイアフラム形式について図 


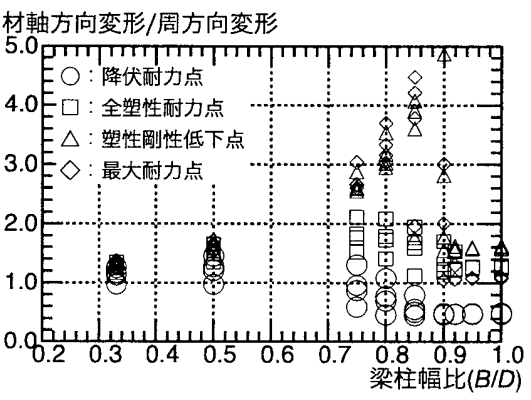

図 9 周方向と材軸方向の変形比

11 図 14 に、通しダイアフラム形式について図 15 図 16 に示す。 図中の荷重 $P$ は接合部局部引張荷重、変形 $\delta$ は接合部局部の変形で、 局部変形計測検長内に梁フランジの梁変形が含まれている場合は、解 析結果に図 7 の応力度一歪度関係に依拠して計算した梁変形も含めて いる。

これらの図より、内ダイアフラム形式及び通しダイアフラム形式共 に、荷重一変形関係モデルは、接合部局部の降伏耐力に達すると剛性 低下が顕著に見られることが分かる。実験結果とモデルは、全塑性 耐力点まで両者はほぼ対応しており、塑性剛性低下点でのモデル $\left.{ }_{c} P\right)$ に対する実験結果 $(e P)$ の耐力比は、内ダイアフラム形式が ${ }_{e} P /{ }_{c} P=0.85$ $\sim 1.20$ (平均值 1.08)、通しダイアフラム形式が ${ }_{e} P l_{c} P=0.98 \sim 1.19$ (平 均值 1.06) と何れの補強形式もモデルと実験結果は比較的良好に対応 しており、本モデルで、接合部局部の荷重一変形関係を塑性域まで概 ね推定できると言える。

内ダイアフラム形式の各パラメータ毎に着目すると、文献 3) によ る梁柱幅比 $(B / D)$ を変化させた試験体 (図 11 参照)、I-1-C2/3-5C $(B /$ $D=1.00) 、 \mathrm{I}-3 / 4-\mathrm{C} 2 / 3-5 \mathrm{C}(B / D=0.75)$ 及び $\mathrm{I}-1 / 2-\mathrm{C} 2 / 3-5 \mathrm{C}(B / D=0.50)$ の比較
に於いて、全塑性耐力点まで、実験結果と本モデルは、比較的良好に 対応しているが、以後、塑性剛性低下点でのモデルに対する実験値の 耐力比は、 $B / D=1.00 、 0.75$ 及び 0.50 に対して、各々 $0.98 、 1.10$ 及び 1.18 と、梁柱幅比が小さくなる程、実験結果に比較して、モデルの耐力が 小さくなる様相を呈している。又、多角形のダイアフラム開口を有す る文献 5) による梁柱幅比 $(B / D)$ 及び開口形状を変化させた試験体 (図 12 参照 ) に於いて、O-9-1/2-FC-H60(B/D=0.50) 及び O-9-1/3-FC-H60(B/ $D=0.34)$ を比較すると、前述の如く梁柱幅比が小さくなる程、実験結 果に比較して、モデルの耐力が幾分小さくなる傾向にある。他方、開 口形状に関して、O-9-1/2-FC-H60(八角形) 及び R-9-1/2-FC-H60(四角 形 ) の比較に於いては、何れも実験結果とモデルの対応は塑性域まで 良好に対応している。

文献 6) による梁柱幅比 $(B / D)$ 、鋼管径 $(D)$ に対するダイアフラム開 口径 $\left.{ }_{d} D\right)$ の比 $\left(_{d} D / D\right)$ 及び鋼管幅厚比 $\left(D / l_{c} t\right)$ を変化させた試験体 $($ 図 13 参照 ) に於いて、C5-8I $(B / D=0.53)$ 及び C10-14I $(B / D=1.00)$ を比較す ると、 $B / D=0.53$ 実験結果とモデルは良好に対応しており、 $B / D=1.00$ ではモデルの方が塑性剛性低下点で実験結果より 2 割程度大きな值 を示している。前述の如く梁柱湢比が小さくなる程、モデルの方が 耐力を低めに評価することは前述と類似傾向である。他方、C $5-8 \mathrm{l}\left({ }_{d} D /\right.$

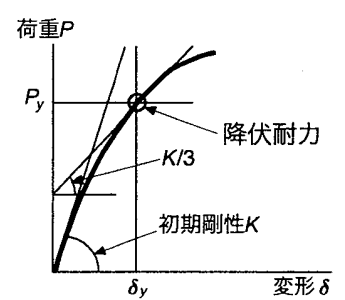

図 10 実験結果の降伏耐力定義

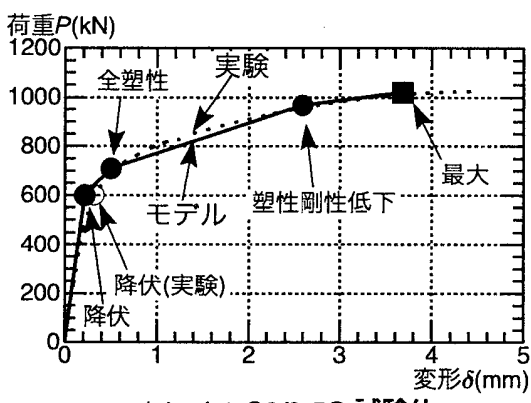

(a) $\mathrm{I}-1-\mathrm{C} 2 / 3-5 \mathrm{C}$ 試験体

$\left(B / D=1.00,{ }_{d} D / D=0.66, D / c t=35.1\right)$

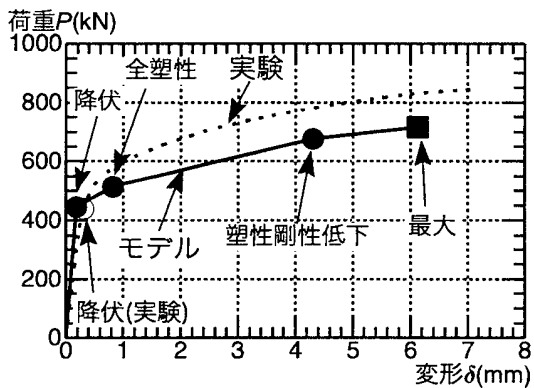

(b) $1-3 / 4-C 2 / 3-5 C$ 試験体

( $\left.B / D=0.75,{ }_{ه} D / D=0.66, D / c t=35.1\right)$

図 11 文献 3)の内ダイアフラム形式実験結果とモデルの比較

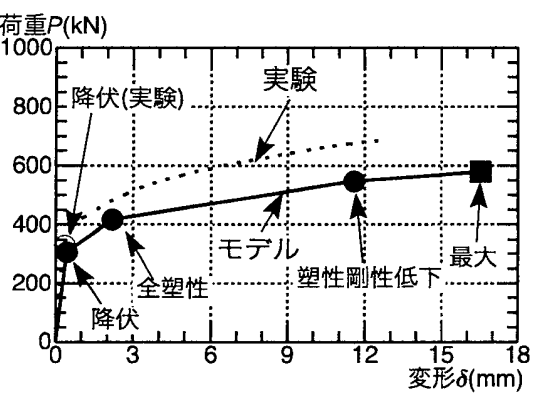

(c) $1-1 / 2-C 2 / 3-5 C$ 試験体 $\left(B / D=0.50,{ }_{d} D / D=0.66, D / c t=33.3\right)$

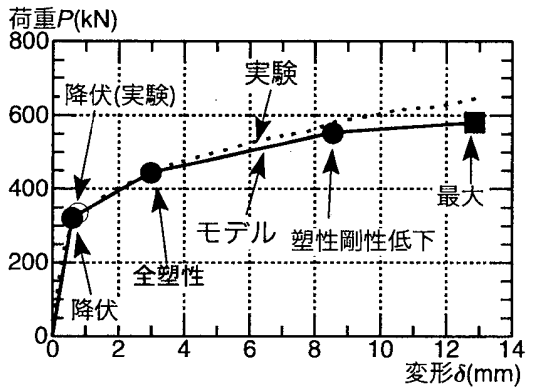

(a) O-9-1/2-FC-H60 試験体

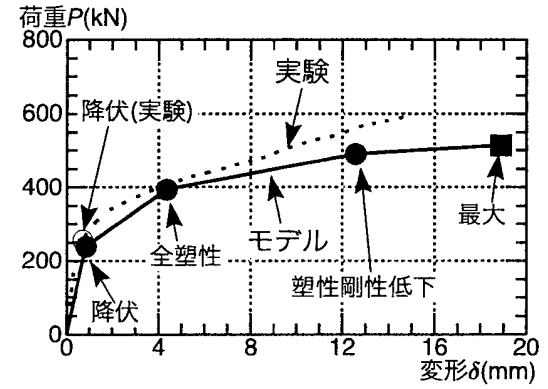

(b) O-9-1/3-FC-H60 試験体

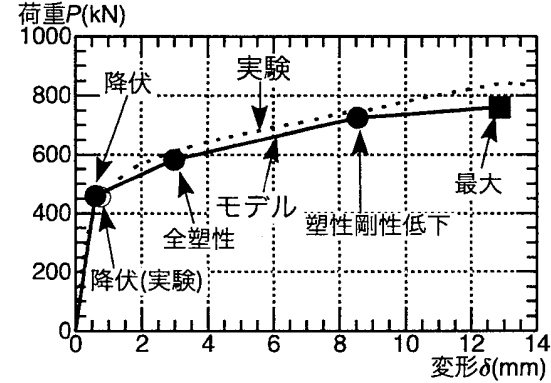

(c) R-9-1/2-FC-H60 試験体

( 八角形開口、 $B / D=0.50,{ }_{d} D / D=0.67, D / c t=34.9$ ) ( 八角形開口、 $B / D=0.34,{ }_{d} D / D=0.67, D /{ }_{c} t=35.1$ ) (四角形開口、 $B / D=0.50,{ }_{d} D / D=0.46, D / c t=34.9$ ) 図 12 文献 5) の内ダイアフラム形式実験結果とモデの比較 


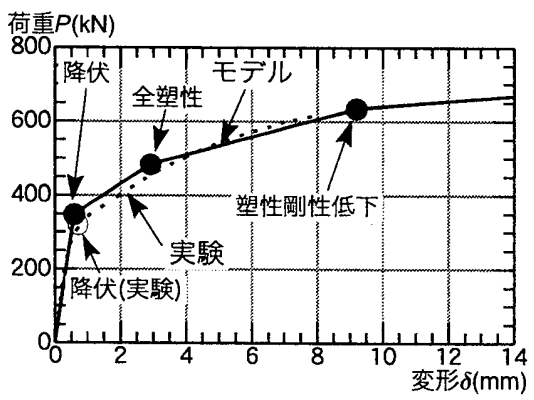

(a) C5-8I 試験体

$\left(B / D=0.53,{ }_{d} D / D=0.70, D / c t=33.3\right)$

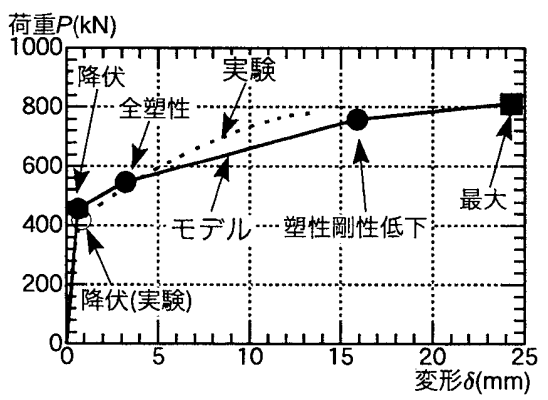

(b) C6-8II 試験体

$\left(B / D=0.60,{ }_{d} D / D=0.40, D / c t=50.0\right)$

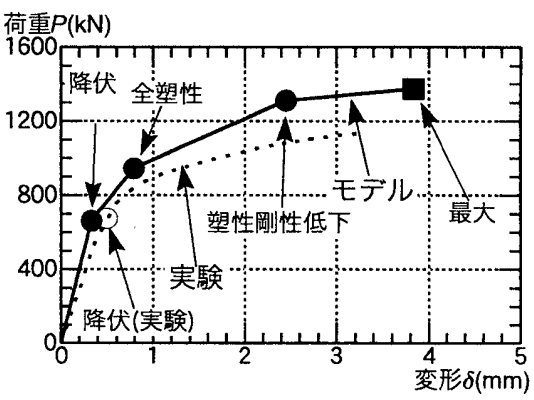

(c) C10-14I 試験体

$\left(B / D=1.00,{ }_{d} D / D=0.70, D / c t=33.3\right)$

図 13 文献 6) の内ダイアフラム形式実験結果とモテルの比較

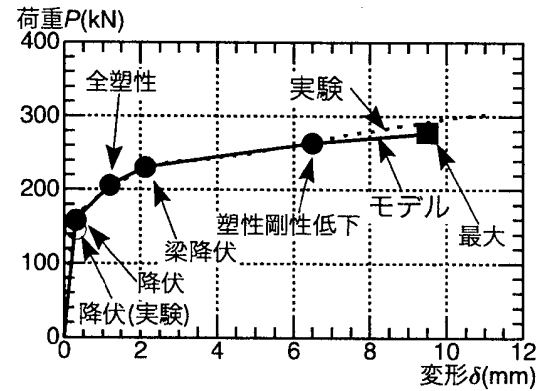

(a) IC-35-130 試験体

$\left(B / D=0.65,{ }_{d} D / D=0.74, D / c t=34.6\right)$

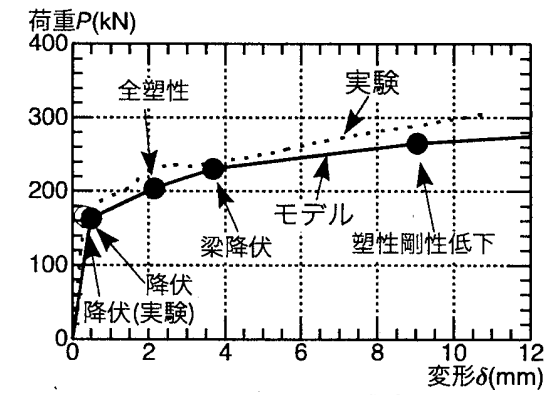

(b) IC-50-130 試験体

$\left(B / D=0.65,{ }_{\alpha} D / D=0.64, D / c t=48.6\right)$

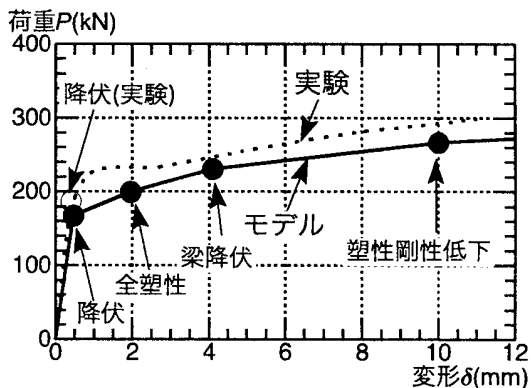

(c) IC-65-130 試験体

$\left(B / D=0.65,{ }_{d} D / D=0.54, D I_{c} t=64.8\right)$

図 14 文献 4) の内ダイアフラム形式実験結果とモデルの比較

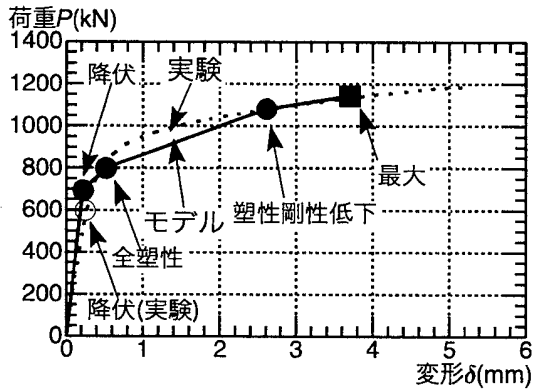

(a) E-1-C2/3-5C 試験体

(B/D=1.00, $ه / D=0.66, D / c t=35.7)$

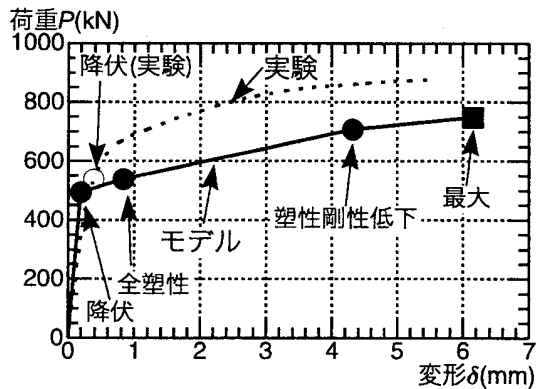

(b) E-3/4-C2/3-5C 試験体

$\left(B / D=0.75,{ }_{d} D / D=0.66, D / c t=35.7\right)$

図 15 文献 3) の通しダイアフラム形式実験結果とモデルの比較

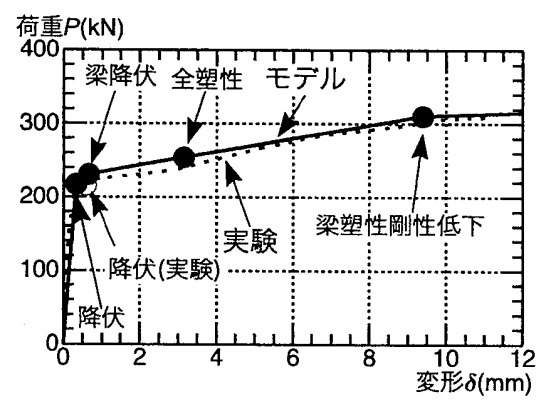

(a) TC-35-130 試験体

$\left(B / D=0.65,{ }_{d} D / D=0.60, D / c t=34.6\right)$

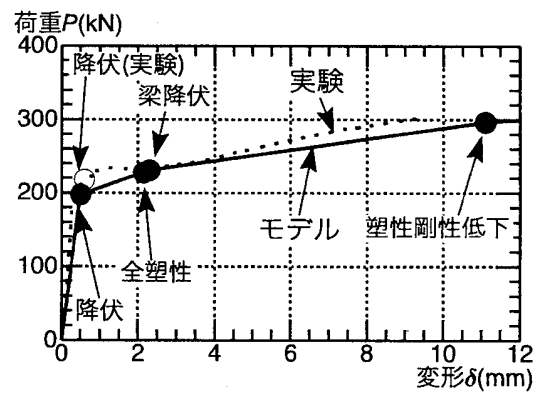

(b) TC-50-130 試験体

( $\left.B / D=0.65,{ }_{d} D / D=0.60, D / c t=48.6\right)$

図 16 文献 4)の通しダイアフラム形式実験結果とモテルの比較

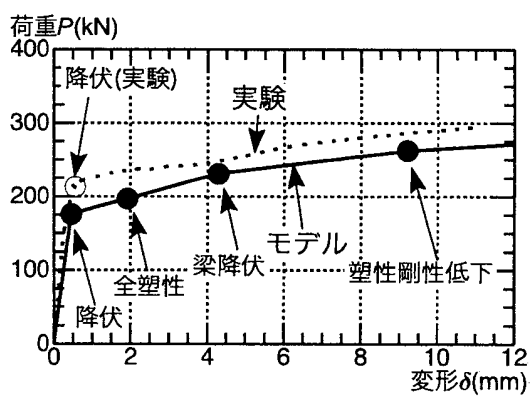

(c) TC-65-130 試験体

$\left(B / D=0.65,{ }_{d} D / D=0.60, D I_{c} t=64.8\right)$
$D=0.70 、 D / c t=33.3)$ と C6-8II $\left({ }_{d} D / D=0.40 、 D / l_{c} t=50.0\right)$ を比較すると、C68II の方が鋼管耐力に対するダイアフラム耐力の比が大きくなるが、 実験結果とモデルの対応の差異は見られない。又、文献 4)による鋼 管径・ダイアフラム開口径比 $\left.{ }_{d} D / D\right)$ 及び鋼管幅厚比 $(D / c t)$ を変化さ せた試験体 (図 14 参照) に於いて、IC-35-130( $\left.{ }_{d} D / D=0.74 、 D / c t=34.6\right) 、$ IC-50-130( $\left.{ }_{d} D / D=0.64 、 D / l_{c} t=48.6\right)$ 及 び IC-65-130( $\left.{ }_{d} D / D=0.54 、 D / l_{c} t=64.8\right)$
の順に、鋼管耐力に対するダイアフラム耐力の比が大きくなるが、図 13 と同様に、何れも実験結果とモデルの対応は良好であり、鋼管・ ダイアフラム耐力比による差異は見られない。

一方、通しダイアフラム形式の各パラメータ毎に着目すると、文献 3)による梁柱幅比 $(B / D)$ を変化させた試験体 (図 15 参照)、E-1-C2/3$5 \mathrm{C}(B / D=1.00)$ 及び $\mathrm{E}-3 / 4-\mathrm{C} 2 / 3-5 \mathrm{C}(B / D=0.75)$ を比較検討すると、内ダ 


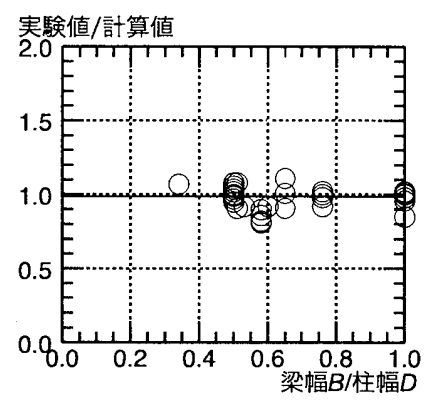

(a) 内ダイアフラム形式

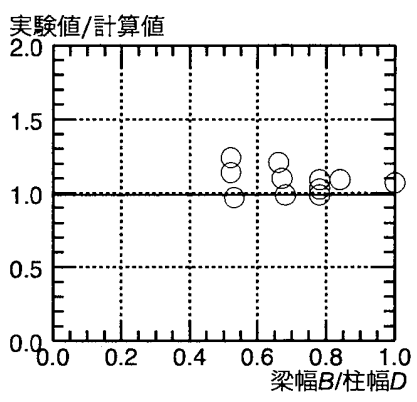

(b) 通しダイアフラム形式

図 17 降伏耐力の実験値と計算値の比較

表 3 実験資料

\begin{tabular}{|c|c|c|c|}
\hline \multicolumn{2}{|r|}{ 接合部 形 式 } & 内ダイアフラム形式 & 通しダイアフラム形式 \\
\hline \multicolumn{2}{|r|}{ 試 験 体 数 } & 31 & 16 \\
\hline \multirow{5}{*}{ 鋼 } & 降伏点 $\left(\mathrm{N} / \mathrm{mm}^{2}\right)$ & $244 \sim 837$ & $244 \sim 399$ \\
\hline & 引張強さ $\left(\mathrm{N} / \mathrm{mm}^{2}\right)$ & $304 \sim 866$ & $304 \sim 526$ \\
\hline & 幅原比/ct & $23.3 \sim 64.8$ & $28.7 \sim 64.8$ \\
\hline & 一般化幅厚比 & $1.00 \sim 2.23$ & $1.26 \sim 2.23$ \\
\hline & 梁フランジ幅B/柱鋼管幅D & $0.34 \sim 1.00$ & $0.28 \sim 1.00$ \\
\hline \multirow{4}{*}{ ダイアフラム } & 降伏点 $\left(\mathrm{N} / \mathrm{mm}^{2}\right)$ & $273 \sim 573$ & $259 \sim 382$ \\
\hline & 引張強さ $\left(\mathrm{N} / \mathrm{mm}^{2}\right)$ & $432 \sim 717$ & $392 \sim 531$ \\
\hline & 開口徍 $d D /$ 柱鋼管幅D & $0.34 \sim 0.74$ & $0.45 \sim 0.72$ \\
\hline & ダイアフラム板幥 $t /$ /鎆管板澋 $c t$ & $0.77 \sim 2.85$ & $1.00 \sim 2.85$ \\
\hline
\end{tabular}

1):一般化幅厚比はD $/ \mathrm{ct} \cdot \sqrt{\mathrm{d}}(\sigma \mathrm{y} / \mathrm{sE})$ によって算定した。

$D ：$ 鋼管径、ct：鋼管板厚、 $c \sigma_{y} ：$ 降伏点、 $s E ：$ ヤング率

イアフラム形式と同様に、梁柱幅比が小さくなる程、実験結果に比 較して、モデルの耐力が小さくなる様相を呈している。又、文献 4) による鋼管幅厚比 $(D / c t)$ を変化させた試験体 (図 15 参照) に於いて、 $\mathrm{TC}-35-130(D / c t=34.6) 、 \mathrm{TC}-50-130(D / c t=48.6)$ 及 び TC-65-130(D/ct=64.8) の順に、鋼管耐力に対するダイアフラム耐力の比が大きくなるが、内 ダイアフラム形式と同様に、何れも実験結果とモデルの対応は良好で あり、鋼管・ダイアフラム耐力比による差異は見られない。

\section{2 耐 力}

降伏耐力及び最大耐力に関して、文献 3) 〜文献 8) の内ダイアフラ ム形式試験体及び文献 3)、文献 8) 〜文献 9) の通しダイアフラム形式 試験体に基づき、実験結果と本モデルを比較した結果を、降伏耐力及 び最大耐力について、各々図 17 及び図 18 に示す。尚、比較検討に用 いた試験体の因子の範囲を表 3 に示す。

降伏耐力に関しては、内ダイアフラム形式が実験值 / 計算値 $=0.81$ 〜 1.11 (平均值 0.98 、変動計数 0.08)、通しダイアフラム形式が実験 值 / 計算值 $=0.97 \sim 1.24$ （平均值 1.08 、変動計数 $0.08 ）$ と、通しダイ アフラム形式では、実験值に対して本モデルの方が低めの值を示して いるが、両形式共に、比較的良好に実験值と計算值は対応している。 他方、最大耐力については、内ダイアフラム形式が実験值 / 計算值 $=$ $0.83 \sim 1.29$ (平均值 1.07、変動計数 0.12)、通しダイアフラム形式が 実験值 / 計算値 $=0.88 \sim 1.24$ （平均值 1.06、変動計数 0.07） となって おり、両形式共、実験值に対して本モデルの方が低めの值を示す傾向 にあるが、ほぼ良好に対応している。尚、これらの実験值と計算値の 対応は、梁柱幅比の変化に依る影響は顕著でない。

\section{4 結 論}

本研究は、内部補強形式である内ダイアフラム形式及び通しダイア フラム形式の角形 CFT 柱梁接合部局部の弾塑性性状を簡便に予測す

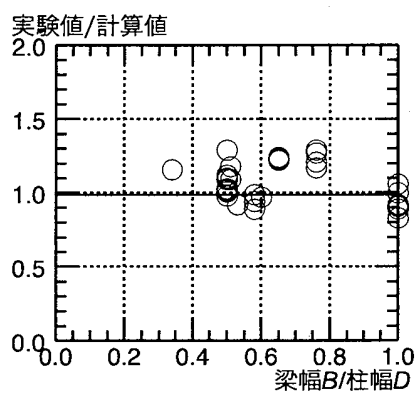

(a) 内ダイアフラム形式

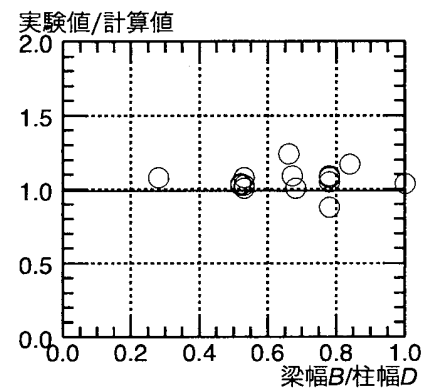

(b) 通しダイアフラム形式 図 18 最大耐力の実験値と計算値の比較

ると共に、一つのモデルで広範囲な梁柱幅比に対応できる荷重一変形 関係モデルの構築を目的とし、鋼管フランジを格子梁に、ウェブを引 張抵抗モデルに置換し、荷重一変形関係モデルを求め、その各点に、 ダイアフラムの耐力を累加して求める接合部局部の荷重一変形関係モ デルを案出した。又、提案モデルの妥当性を検証する為、既往の実験 資料と本モデルとの比較検討を行った。

本モデルと実験結果を比較すると、全塑性耐力点まで両者はほぼ対 応しており、塑性域でのモデル $\left.{ }_{c} P\right)$ に対する実験結果 $(e \mathrm{P})$ の耐力比は、 内ダイアフラム形式が ${ }_{e} P /{ }_{c} P=0.85 \sim 1.20$ (平均值 1.08)、通しダイアフ ラム形式が ${ }_{e} P / c P=0.98 \sim 1.19$ (平均値 1.06) と何れの補強形式も本モ デルと実験結果は比較的良好に対応しており、本モデルで、実際に用 いられ広範囲な梁柱幅比 ( 梁幅 / 柱幅 $=1 / 3 \sim 1$ ) に対して、接合部局 部の荷重一変形関係を塑性域迄、概ね推定できることが把握された。 又、降伏耐力に関して、実験值と計算值の対応は比較的良好であり、 最大耐力について、計算值が幾分実験值に比較し、低い值を示すがほ ぼ良好に対応する結果であった。

\section{参考文献}

1) 日本建筑学会：鉄骨鉄筋コンクリート構造計算規準・同解説、第 5 版、 2001.1.10

2）福元敏之、森田耕次：コンクリート充てん角形釦管柱・鉄骨はりの内部補 強形式接合部に関する研究一接合部局部の弾塑性性状一、日本建筑学会 構造系論文集、No.528、pp.175 182、2000.2

3) 福元敏之、㴰 正哉 : コンクリート充填角形鋼管柱・鉄骨梁接合部局部の 弾塑性性状に関する研究 一梁幅が広い内部補強形式接合部一、日本建筑 学会構造系論文集、No.560、pp.213〜220、2002.10

4) 河野昭彦、松井千秋、村井 望：コンクリート充填角形銅管柱と H 形銅梁 のダイアフラム補強型接合部の局部変形に対する荷重一変形関係モデル、 鋼榡造論文集、第 5 巻、第 17 号、pp93 104、1998.3

5) 福元敏之、小林 創：高強度材料を用いたコンクリート充てん角形鋼管柱・ 鉄骨ばりの内部補強形式仕口に関する研究 一局部の弾塑性性状一、日本 建築学会構造系論文集、No.479、pp.109〜 118、1996.1

6) 森田耕次、横山幸夫、川又康博、松村弘道：コンクリート充てん角形鋼管 柱一鉄骨はり接合部の内ダイアフラム補強に関する研究、日本建築学会構 造系論文報告集、第 422 号、pp.85 96、1991.4

7) 森田耕次、寺岡 勝、鈴木孝彦、藤原敏夫、銷流馬久明 : 高張力鋼を用い たコンクリート充てん角形鐷管柱－鉄骨はり接合部の力学的挙動に関する 研究、日本建筑学会構造系論文報告集、第 446 号、pp.127 136、1993.4

8) 渡辺一弘、菊川和俊、鴨下直樹、中嶋和子：コンクリート充填角形鋼管柱 梁接合部に関する研究 (その1。接合部フランジ引張実験の概要) (そ の 2. 接合部フランジ引張実験の結果及びまとめ)、日本建築学会大会学術 講演梗概集 (九州) ・構造III、pp.1165〜 1168、1998.9

9) 松井千秋、近藤 清 : コンクリート充填角形鋼管柱と H 形鋼はりの接合部 に関する研究 (単純引張型試験体を用いた実験)、日本建築学会大会学術 講演梗概集 (関東) ・構造系、pp.1661 1662、1979.9

（2007年 2 月 5 日原稿受理，2007年 4 月 10 日採用決定） 